\title{
PENGAMPUNAN PIDANA DALAM MEWUJUDKAN KEADILAN, KEPASTIAN DAN KEMANFAATAN
}

\author{
A.Rachmat Wirawan ${ }^{1}$, Avelyn Pingkan Komuna ${ }^{2}$ \\ 1,2 Program Studi Ilmu Hukum, FHISIP, Universitas Terbuka \\ e-mail: rachmat.wirawan@ecampus.ut.ac.id
}

Article Info

\section{Keyword:}

transparancy;

policy;

society participant;

supervision;

digitalization

\section{Abstract}

This paper tries to provide a perspective on the current administration of the Indonesian criminal law system. How justice, certainty and benefit is a complete form of the objectives of the criminal law itself. Not only from the victim's perspective, it must also be considered from the perspective of the defendant. However, the reality of the administration of the criminal law system focuses more on the concepts of justice and certainty. As if putting aside the principle of benefit from the purpose of law that has long been imprinted. The result is that many parties do not feel the true form of justice. Justice is when a case ends in court it becomes a doctrine. The implementation of norms that tend to be posivist leads to the opinion that law enforcement is only a mouthpiece of law. The settlement of a case is only viewed in the "fair and certain" dimension. "Fair" with the imposition of moderate "definite" sanctions with binding judges' decisions. Meanwhile, the principle of benefit has not yet found its true form. For this reason, it is necessary to carry out a transformation from the current criminal law system. The application of a legal system that is not only based on fairness and certainty also benefits the parties. The research method used is descriptive qualitative with a conceptual normative approach that makes legal comparisons with various legal studies and examples of related cases. With the results to be achieved is the realization of justice, certainty and full benefit based on the principle of criminal amnesty.

\section{Article Info}

Kata Kunci:

sistem hukum pidana;

keadilan;

kepastian;

kemaslahatan

\section{Abstrak}

Tulisan ini mencoba memberikan perspektif dari penyelenggaraan sistem hukum pidana Indonesia saat ini. Bagaimana keadilan, kepastian dan kemanfaatan merupakan satu wujud utuh dari tujuan hukum pidana itu sendiri. Bukan hanya dari perspektif korban, juga harus diperhatikan dari perspektif terdakwa. Namun realita penyelenggaraan sistem hukum pidana, lebih menitikberatkan pada konsep keadilan dan kepastian. Seolah mengenyampingkan asas kemanfaatan dari tujuan hukum yang sudah lama terpatri. Hasilnya banyak pihak tidak merasakan wujud dari keadilan yang sejati. Keadilan adalah ketika perkara putus di pengadilan menjadi sebuah doktrinisasi. Penyelenggaraan norma yang cenderung positivis menggiring opini bahwa penegakan hukum hanya sekedar corong dari undang-undang. Penyelesaian perkara hanya dipandang dalam dimensi "adil dan pasti". "Adil" dengan penjatuhan sanksi sedang "pasti" dengan putusan hakim pengadilan yang sifatnya mengikat. Sedang asas manfaat belum menemukan wujudnya yang hakiki. Untuk itu perlu dilakukan transformasi dari sistem hukum pidana saat ini. Penerapan sistem hukum yang tidak hanya bertumpu pada adil dan 
pasti juga memperoleh manfaat bagi para pihak. Adapun metode penelitian yang digunakan adalah deskriptif kualitatif dengan pendekatan normatif konseptual yang melakukan perbandingan hukum dengan berbagai kajian hukum dan contoh kasus terkait. Dengan hasil yang ingin dicapai adalah terwujudnya keadilan, kepastian dan kemanfaatan secara utuh dengan asas pengampunan pidana.

\section{Pendahuluan}

Hukum pidana memiliki peran untuk membatasi kewenangan dan hak dari setiap subjek hukum. Hukum pidana yang harusnya menjadi alternatif terakhir dalam penyelesaian konflik antar subjek, kemudian menjadi opsi pertama dalam penanganan konflik yang timbul dari adanya pergeseran hak antar individu ataupun kelompok. Peran hukum pidana dalam pergumulan kehidupan subjek dalam masyarakat hukum, selain sebagai pelindung hak namun sekaligus sebagai perampas hak dengan konsep keadilan formal.

Formulasi dalam perumusan sistem pemidanaan Indonesia pada saat ini masih merupakan karya monumental belanda semasa penjajahan. Penyusunan peraturan yang dibuat lebih berorientasi pada penghukuman pelaku tindak pidana. Secara filosofis nilai yang menjadi latar belakang pembentukan aturan pemidanaan pada KUHP/WvS menitik beratkan pada perbuatan dan pelaku tindak pidana.

Sejatinya pada konsep hukum pidana Indonesia perlu dilakukan restorasi. Hal ini didasari bahwa pengamalan hukum pidana masih belum bisa melihat sisi nilai yang tumbuh hidup di tengah masyarakat. Hukum seolah dipandang sebagai sarana penghakiman atau alat untuk membalas dendam. Padahal telah nyata adanya, bahkan telah digaungkan pasca kemerdekaan bahwa ide pokok penyusunan tiap aturan di Indonesia adalah berasaskan Pancasila. Nilai luhur dalam Pancasila yang menjadi konsepsi dasar bagi penyusunan ketentuan hukum pidana yang baru. Konkritisasi nilai Ketuhanan, kemanusiaan dan kemasyarakatan akan melahirkan aturan yang bukan hanya melihat dari sisi keadilan dan kepastian hukum saja, namun juga melihat pada sisi kemanfaatan.

Pada dasarnya sistem hukum pidana di Indonesia lebih mengedepankan pola positivis. Hukum dan penerapannya memandang perkara atau konflik hukum pada ranah keadilan dan kepastian namun mengenyampingkan sebuah fakta bahwa ada sisi kemanfaatan. Wujud kemanfaatan dapat dianggap sebagai buah dari keadilan dan kepastian melalui terompah hakim dipersidangan. Hingga melupakan sebuah fakta bahwa ada banyak konflik hukum yang tidak perlu berakhir dengan hukuman. Akibatnya banyak kasus-kasus kecil seperti pencurian kayu, sendal hingga buah yang notabene nya memiliki nilai rupiah yang tidak seberapa dijatuhi pidana yang tidak sesuai bahkan bertentangan dengan nilai-nilai kemanusiaan yang hidup di masyarakat.

Namun ketika kita merujuk syarat pada sistem hukum pidana dalam KUHP bahwa pidana dapat dijatuhkan apabila memenuhi kondisi adanya perbuatan dan kesalahan maka itu sudah menjadi dalih yang kuat bagi hakim dan penegak hukum untuk melaksanakan proses peradilan. Dengan bertumpu pada kedua syarat itu dalam proses penyelesaian perkara pidana maka keadilan dan kepastian hukum mungkin dapat ditegakkan namun kemanfaatan yang dihasilkan dari sisi pelaku maupun korban kemungkinan tidaklah memiliki wujud konkrit. Dampak lainnya yang akan timbul adalah perkara yang semakin menumpuk dengan berbagai konflik hukum yang ada, serta imbas lainnya pada penanganan perkara pidana adalah Rutan maupun Lapas sebagai sarana penitipan tahanan akan melebihi kapasitas yang sudah disediakan untuk menampung narapidana.

Berdasar pada uraian dalam latar belakang di atas, maka dilakukan pengkajian dan penulisan dengan judul asas pengampunan pidana dalam mewujudkan keadilan, kepastian dan kemanfaatan.

\section{Metode Penelitian}

Artikel ini berdasar pada penelitian data secara yuridis normatif dan sosiologis yang mengkaji proses permasalahan berdasar kaidah hukum dan norma hukum kemudian memperbandingkan 
dengan pemberlakuan asas dalam hukum positif. Pendekatan penelitian menggunakan metode konseptual dan pendekatan perundang-undangan (statute approach) dengan melihat pandangan atau doktrin yang berkembang dalam ilmu hukum yang bertujuan munculnya ide, gagasan baru terkait konsep dan asas hukum yang relevan dengan isu hukum.

Penelusuran materi tulisan artikel ini melalui studi dokumen atau kepustakaan (library research) dengan mengumpulkan sejumlah literatur, dokumen, pendapat pakar serta artikel hukum yang telah publish. Metode yang digunakan adalah deskriptif analisis yang mengacu pada suatu masalah tertentu yang kemudian dikaitkan dengan literatur, pendapat pakar maupun berdasar perundang-undangan.

\section{Pembahasan}

1. Asas Keadilan, Kepastian dan Kemanfaatan

Keadilan, kepastian dan kemanfaatan merupakan nilai identitas untuk mewujudkan tujuan dari hukum. Keberlakuan asas ini merujuk pada bagaimana implementasi hak yang sama untuk semua orang di depan pengadilan, jaminan penyelesaian konflik secara yuridis sehingga memberikan kemanfaatan dari sisi korban bahkan pelaku.

Keadilan menurut L.J Van Apeldoorn tidak boleh dipandang sama arti dengan penyamarataan, keadilan bukan berarti bahwa setiap orang memperoleh bagian yang sama. Pada dasarnya keadilan yang dirasakan akan berbeda pada satu orang dengan orang yang lainnya. Sehingga keadilan sebagai tujuan hukum dituntut untuk menciptakan keseimbangan antar kepentingan-kepentingan yang dilindungi dan setiap orang mendapatkan sesuai dengan haknya. Pengkajian keadilan secara yuridis harus juga berbarengan dengan konsepsi nilai-nilai filosofis sosiologis masyarakat, dengan maksud untuk mewujudkan keadilan yang mengakomodir rasa keadilan masyarakat bukan hanya berdasar pada rasa keadilan delegasi pemerintah yaitu melalui pengadilan.

Kepastian secara normatif merupakan suatu peraturan perundangan yang dibuat dan diundangkan secara pasti, mengatur secara logis dan jelas sehingga dapat menghindari multitafsir yang dapat memicu terjadi benturan dan konflik norma. Konflik norma yang timbul dari ketidakpastian hukum dapat berbentuk kontestasi norma, reduksi norma hingga distorsi norma. Menurut Utrecht kepastian hukum mengandung dua pengertian; pertama adanya aturan yang bersifat umum membuat individu mengetahui perbuatan apa yang boleh dan tidak boleh dilakukan dan kedua berupa keamanan hukum bagi individu dari kesewenangan pemerintah karena adanya aturan yang bersifat umum mengenai apa saja yang boleh dan tidak boleh dibebankan atau dilakukan oleh negara.

Kemanfaatan adalah asas yang menyertai asas keadilan dan kepastian hukum. Merujuk tujuan dari hukum, seharusnya dalam proses penerapan hukum bukan hanya memperhatikan aspek keadilan dan kepastian namun juga patut dipertimbangkan dari aspek kemanfaatan, baik itu dari pihak korban maupun dari pihak pelaku. Sebagai contoh kasus pelanggaran pasal 362 dalam kategori pencurian biasa dengan obyek pencurian berupa kayu bakar yang dilakukan oleh terdakwa ibu berusia 60 tahun maka dalam penjatuhan hukuman patut dipertimbangkan aspek kemanfaatan dari penjatuhan hukuman penjara atau kurungan, apa dampak secara signifikan bagi terdakwa sendiri dan kepada masyarakat.

\section{Sistem hukum pidana Indonesia}

Jika menilik pada bagaimana aktualisasi dari penerapan sistem hukum pidana di Indonesia, masih ditemukan fakta menarik bahwa kecenderungan sistem hukum yang berorientasi pada pola positivis. Positivisme hukum dikenal juga sebagai teori hukum yang menganggap bahwa pemisahan antara hukum dan moral, merupakan hal yang penting. Harus ada sekat yang jelas antara hukum dengan anasir lainnya, tidak boleh tercampur aduk antara norma hukum dengan nilai di luar hukum. Bagi kaum positivis, norma hukum yang "bengis" pun, dapat diterima sebagai hukum asalkan 
memenuhi kriteria formal yang ada tentang hukum.

Dalam ajaran positivis sistem hukum adalah suatu "sistem logis tertutup" dimana putusanputusan hukum yang tepat dapat dihasilkan dengan cara yang logis dari peraturan-peraturan hukum yang telah ditentukan terlebih dahulu tanpa mengingat tuntutan sosial, kebijaksanaan dan normanorma moral. Dilihat dari bentuknya, teori positivisme hukum memandang hukum adalah undangundang; dilihat dari isinya hukum adalah perintah dari penguasa. Hukum dipandang sebagai regulatif bukan unsur konstitutif. Hukum tidak memenuhi rasa keadilan tetap disebut hukum, walaupun merupakan hukum yang buruk.

Sejatinya sistem hukum Indonesia yang terpengaruh romantisme positivisme cenderung memandang hukum sebagai alat untuk melakukan penghukuman kepada pelaku tindak pidana. Hal ini dapat terlihat dari jumlah pelaporan, penanganan hingga putusan perkara tindak pidana ,khususnya tindak pidana ringan di Indonesia.

Tabel 1. Data jumlah penanganan kasus tindak pidana 2017-2021

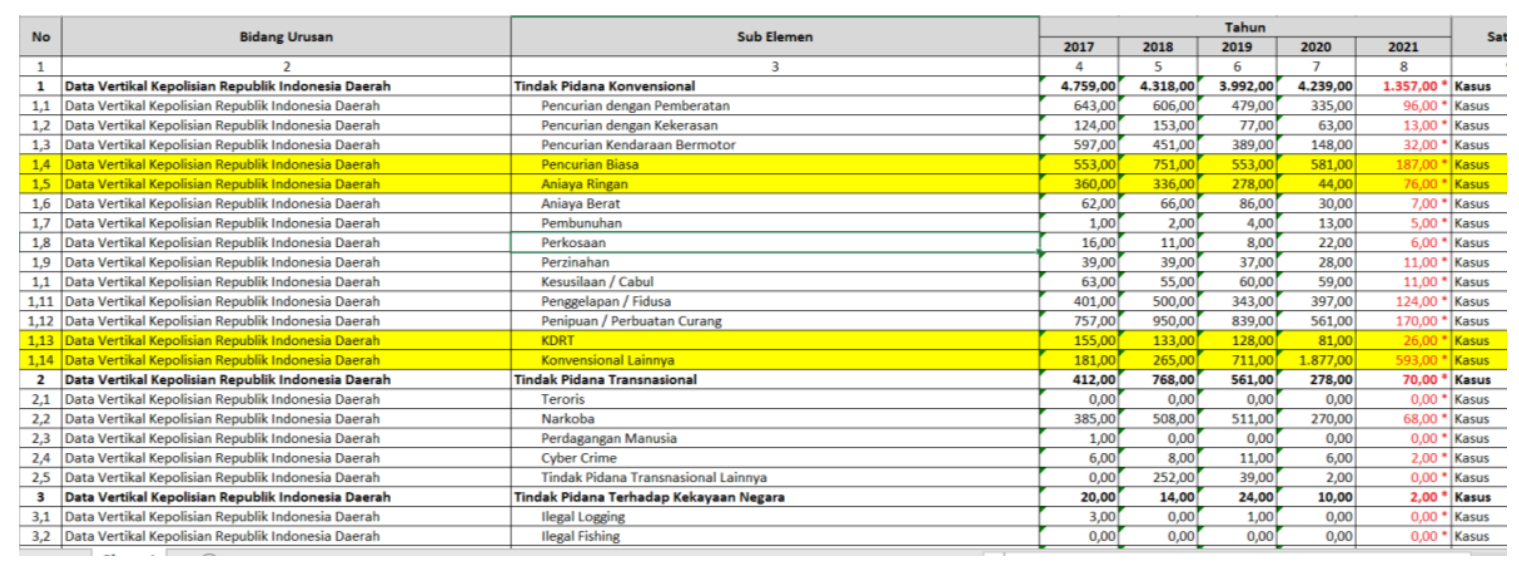

Sumber : dataku, data vertical kepolisian daerah Yogyakarta.

(http://bappeda.jogjaprov.go.id/dataku/data_dasar/index/547-data-tindak-pidana?id_skpd=39)

Dari data pada kolom di atas, tampak bahwa jumlah penanganan kasus hingga putusan dalam hal aniaya ringan misalnya, masih berparadigma penghukuman atau penjatuhan sanksi kepada pelaku. Keadilan masih dipandang pada perspektif penerapan sanksi dan hukuman badan berupa kurungan atau penjara. Walaupun terjadi penurunan kasus yang cukup signifikan pada tahun 2020 namun ini ditengarai karena kurangnya kontak langsung antar individu selama masa pandemi sehingga potensi terjadinya penganiayaan ringan jadi berkurang.

Hal yang patut menjadi perhatian adalah jumlah berkas kasus yang harus masuk ke meja pengadilan dalam hal penganiayaan ringan. Ketika merujuk pada sistematika penanganan perkara pidana membutuhkan waktu yang relatif lama, biaya yang membengkak dan kebutuhan akan ruang tahanan titipan kejaksaan ataupun yang telah menjadi warga permasyarakatan semakin tak terelakkan. Membludaknya kasus yang harus ditangani melalui wilayah litigasi, membuat Rutan maupun Lapas menjadi over kapasitas.

Dari sini dapat ditarik sebuah konklusi bahwa sistem hukum saat ini baik yang merujuk pada KUHP ataupun luar KUHP masih belum mengakomodir pemikiran tentang asas pengampunan pidana pada perkara yang dikategorikan sebagai tindak pidana ringan.

\section{Pembaharuan sistem hukum indonesia}

Pembaharuan terhadap konsepsi hukum pidana Indonesia telah lama digaungkan oleh banyak pihak. Kalangan politisi hingga akademisi mewacanakan tentang rekonstruksi materi muatan dalam KUHP yang notabene merupakan karya dari penjajah, yang secara turun temurun menjadi pedoman penegakan hukum di Indonesia. Pada hakikatnya pemikiran untuk melakukan pembaharuan terhadap KUHP adalah suatu hal yang tepat, mengingat perubahan persepsi dan paradigma berfikir 
masyarakat yang juga mengalami perubahan sesuai dengan kebiasaan-kebiasaan yang hidup di masyarakat. Namun harapannya bahwa pembaharuan yang kemudian dilakukan bukan hanya sekedar memperbaharui/ mengganti rumusan pasal secara tekstual namun berpijak pada pendekatan nilai yang hidup dimasyarakat.

Barda Nawawi Arief mengatakan bahwa pembaharuan hukum pidana tidak bisa dilepaskan dari ide/kebijakan pembangunan sistem hukum nasional yang berlandaskan Pancasila sebagai nilainilai berkehidupan kebangsaan yang dicita-citakan. Ini berarti pembaharuan hukum pidana nasional seyogyanya juga dilatarbelakangi dan bersumber/berorientasi pada ide-ide dasar Pancasila yang mengandung nilai/ide/paradigma.

Berdasarkan hal tersebut dalam merumuskan suatu tindak pidana, tidak hanya didasarkan adanya "tindak pidana" dan "kesalahan atau pertanggungjawaban pidana, tetapi juga didasarkan pada tujuan pemidanaan. Pada skema persyaratan pemidanaan memiliki skema bahwa pidana merupakan perpaduan antara tindak pidana degan kesalahan atau pertanggungjawaban pidana.

\section{$\mathrm{PIDANA}=\mathrm{TP}+\mathrm{K}(\mathrm{PJP})$}

Pada skema di atas formula/model/pola konvensional di atas tidak terlihat variabel tujuan, karena tidak disebutkan secara eksplisit. Model demikian jelas terkesan "model kepastian" yang kaku. Lain halnya ketika dimasukkan variabel tujuan pemidanaan dalam syarat pemidanaan, maka dalam keadaan tertentu hakim diberi kewenangan untuk memberi maaf dan tidak menjatuhkan pidana atau Tindakan apapun, walaupun TP dan K telah terbukti.

Padahal dengan penegasan tentang tujuan dari pemidanaan akan membuka ruang berfikir dari para penegak hukum bagaimana seharusnya dalam menyelesaikan sebuah kasus terkait pidana, apakah cukup mengacu pada undang-undang atau menggunakan pendekatan lain dalam penyelesaian perkara atau tindak pidana khusus dalam kategori tipiring atau tindak pidana ringan. Klasifikasi Tipiring atau tindak pidana ringan merupakan delik yang dipandang "sangat ringan" yaitu yang diancam dengan pidana disini ialah delik-delik yang dulunya diancam dengan pidana penjara/kurungan di bawah 1 (satu) tahun atau denda ringan atau delik baru yang bobotnya di bawah 1 (satu) tahun penjara

\section{Asas kemanfaatan dalam Pengampunan Pidana}

Asas pengampunaan pidana merupakan sebuah kaidah tentang pemaafan terhadap perbuatan dari subjek hukum yang dianggap merugikan kepentingan hukum subjek hukum lain namun dalam kategori yang wajar. Pada dasarnya asas ini bukan sebagai dalih untuk membenarkan sebuah tindak pidana yang dilakukan hanya saja membuka satu perspektif lain bahwa ada sisi yang harus dipertimbangkan dalam penyelesaian perkara pidana.

Dalam perkembangan hukum saat ini masih banyak juga praktisi hukum yang berparadigma bahwa pidana adalah satu-satunya reaksi paling tepat atas perilaku yang dianggap menyimpang. Ketika bersesuaian dengan rumusan delik maka pelaku perbuatan harus dikenai dengan pidana. Padahal ketika dikaji lebih jauh hukum pidana tidak boleh hanya berorientasi pada perbuatan manusia saja sebab dengan begitu hukum pidana akan kehilangan unsur moralitasnya, menjadi tidak manusiawi dan mengutamakan pembalasan. Padahal selain itu perlu juga memperhatikan kepentingan yang lebih luas yakni kepentingan masyarakat, kepentingan negara serta kepentingan korban.

Sebagai contoh yaitu kasus nenek minah yang dituduh mencuri 3 biji kakao yang kemudian dihukum percobaan pencurian 1 bulan 15 hari. Pada contoh di atas perbuatan tersebut memenuhi kualifikasi sebagai tindak pidana pencurian yang semata-mata hanya dilihat bahwa perbuatan tersebut memenuhi rumusan pasal 362 KUHP. Fenomena ini membuktikan bahwa hukum pidana di Indonesia sangat kaku dan lebih menjunjung tinggi formalitas sehingga mengabaikan kebenaran 
materiil dan asas kemanfaatan yang merupakan salah satu tujuan dari hukum pidana.

Pengampunan pidana bukan bertujuan untuk meniadakan sanksi pidana namun bagaimana melihat kemanfaatan yang diperoleh dari korban atau pelaku dengan diterapkannya sanksi pidana terhadap pelaku. Dengan memperhatikan asas kemanfaatan dari tujuan hukum pidana secara tidak langsung juga menyandingkan unsur keadilan dengan sebuah kepastian hukum dari putusan pengadilan.

\section{Simpulan}

Jika melihat asas dasar negara Indonesia yakni Pancasila, memang sangat ironi ketika praktikya nilai Pancasila tidak diterapkan secara penuh dalam sistem hukum Indonesia. Praktik hukum pidana Indonesia seolah menegaskan seorang yang terbukti memenuhi rumusan undangundang secara langsung dapat dinyatakan bersalah dan harus dipidana, hal ini mengesankan bahwa tidak adanya aturan yang mencerminkan asas demokrasi, asas kemasyarakatan, asas kemanusiaan, asas keadilan dan asas Ketuhanan.

Dengan dilakukannya pembaharuan hukum pada sistem hukum di Indonesia maka tujuan hukum menjadi salah satu parameter dari penjatuhan sanksi atau hukuman pada pelaku dengan tidak hanya merujuk pada keadilan dan kepastian namun juga mengedepankan nilai kemanfaatan baik itu terhadap korban, kelaurga korban ataupun pelaku tindak pidana.

\section{Daftar Pustaka}

Ardiansyah Nurahman, Eko Suponyono. 2019. Asas keseimbangan dalam rancangan kitab undang-undang hukum pidana sebagai upaya pembaharuan hukum pidana yang berkeadilan. Journal Pandecta. Volume 13 Nomor 2. Desember 2012. Hal 102

Khilmatin Maulidah, Nyoman Serikat Putra Jaya. 2019. Kebijakan formulasi asas permaafan hakim dalam upaya pembaharuan hukum pidana nasional. Jurnal pembangunan hukum Indonesia. Volume 1. No. 3 tahun 2019. Hal 283

Sudiyana, Suswoto. 2018. Kajian kritis terhadap teori positivism hukum dalam mencari keadilan substantif. Jurnal ilmiah ilmu hukum QISTIE. Vol. 11. No. 1 mei tahun 2018. Hal-109

Dataku, data kepolisian daerah Yogyakarta. 2021 retrieved juni 2021 from (http://bappeda.jogjaprov.go.id /dataku/data_dasar/index/547-data-tindakpidana?id_skpd=39

Kejaribone. 2020. Analisis konsep keadilan, kepastian dan kemanfaatan dalam penegakan hukum tindak pidana pertambangan. Retrieved June 18, 2021. From https://www.kejaribone.go.id/artikel/detail/1/analisa-konsep-keadilan-kepastian-dan-kemanfaatan-dalampenegakan-hukum-tindak-pidana-pertambangan.html

Naskah akademik KUHP_BPHN 2009. Retrieved juni 2021. From https:// www.bphn.go.id/da ta/documents /na_ruu_kuhp. Pdf. 